\title{
Lipoproteins as drug delivery vehicles for cancer and tumor therapeutics
}

\begin{abstract}
Present article focuses on various lipoprotein based drug delivery vehicles used in cancer and tumor therapeutics. Starting from aqueous phase delivery through liposomes or unilamellar vesicles, biomimetic HDL nanoparticles, discoidal recombinant high-density lipoproteins (d-rHDLs) are favorably used to deliver anticancer agents. LDL based carrier vehicles are reconstituted in many ways i.e. discoidal SMAaf-based lipid nanoparticles, nanovectors, LDL nanoparticles, SiRNA-HDL used for systemic delivery of short interfering RNA. This article also explains chemically and genetically engineered highdensity lipoprotein (HDL)-like nanodiscs or "bicelles", chylomicrons, and monoclonal antibodies and ligand-coupled lipoprotein as drug delivery vehicles. These are most promising delivery systems for anticancer drugs. Acetylated low-density lipoprotein is also used as a delivery vehicle for anti-infectious drugs. There is immense need of therapies, imaging agents, and drug delivery vehicles to combat rising number of cases of neoplasticity and tumors in population. For safe cancer therapeutics nano-sized sitespecific drug delivery vehicles which might show bio-compatibility, bio-degradability, and receptor-mediated endocytosis are to be developed.
\end{abstract}

Keywords: LDL, HDL, liposomes , lipid nanoparticles , chylomicrons, nanodisks, drug carriers
Volume 4 Issue 3 - 2018

Ravi Kant Upadhyay

Department of Zoology, DDU Gorakhpur University, India

Correspondence: Ravi Kant Upadhyay, Department of Zoology, DDU Gorakhpur University, Gorakhpur, 273009, UP, India, Email rkupadhya@yahoo.com

Received: May 15, 2018 | Published: June 25, 2018

\section{Introduction}

Lipoproteins are biological lipid carriers play important role in transport of fats within the body. ${ }^{1}$ These are natural nanoparticles which serve as drug-delivery vehicles due to their small size, long residence time in the circulation. ${ }^{2}$ Low-density lipoprotein (LDL) carries cholesterol in plasma ${ }^{3}$ and play important role in its metabolism in normal cells as well as in cancer cells. ${ }^{4}$ Lipoproteins carry highdrug payload and are used as delivery vehicles for transportation of chemotherapeutic agents. These bear unique targeting capabilities because of their easy transportation to cancer and tumor sites. LDL loaded with r11-DOX is used to treat cancer cells. LDL follows receptor pathway is used to deliver radionucleotides for the treatment of neoplasms and tumors. ${ }^{5}$ Both liposomes and oil emulsions are also used to carry water-insoluble photosensitizers for treatment of tumors. ${ }^{6}$ Besides, low-density lipoproteins (LDLs) monoclonal antibodies are also most promising delivery vehicles for anticancer drugs. For delivery of therapeutic agents liposomes bind to some antibody and loaded drug are internalized by into macrophages via the receptor-mediated pathway for modified LDL. ${ }^{7}$ More specifically, loaded drug is assimilated through receptor-mediated pathway in cancer cells and its rate is much higher than that of normal cells. For transport of drugs to new targets, lipoproteins are bound to ligands. Lipoproteins structure is modified to tag nucleic acids, photosensitizers for therapeutics. These also act as biophysical devices like contrast agents and can be loaded with drugs, LPs and phospholipids. These natural drug nanocarriers escape any interaction with immune cells and reticuloendothelial systems. ${ }^{8}$ Hence, drugs loaded on LDLs safely transported to tumor cells without loss of their activity. ${ }^{9}$ After receptor-mediated uptake of drug-lipoprotein complex escape enzyme attack. $^{2}$ Lipoproteins are safe, biocompatible, biodegradable, nonimmunogenic and successfully carry diverse therapeutic molecules to the site of invasion.

\section{Lipoproteins: transport vehicles of lipids}

Lipoproteins are major transporters of cholesterol, triglycerides and other hydrophobic molecules in circulatory system (Figure 1). Lipoproteins are natural nanoparticles which also deliver certain lipophilic compounds such as fat-soluble vitamins and hormone and enzyme inhibitors. ${ }^{9-11}$ These also function as drug-delivery vehicles due to their smaller size, low affinity and high capacity binding, longer stay in the circulation. Moreover, both natural and reconstituted lipoprotein based systems are able to carry high high-drug payload ${ }^{12}$ and are used for delivery of therapeutic molecules (Figure 2). ${ }^{13}$ Based on their density, lipoproteins are categorized as chylomicron, very low density lipoprotein (VLDL), intermediate density lipoproteins (IDL), low density lipoprotein (LDL) and high density lipoprotein (HDL).

HDL (high-density lipoproteins) is smallest lipoprotein that also transports cholesterol from various tissues and back to the liver. These are composed of lipids, hydrocarbons, proteins, and nucleic acids (eg. microRNA). HDL is denser and small lipoprotein that can carry lipids in form of aggregates in plasma. HDL possesses high protein / lipid ratio and non harmful as it load less cholesterol and play important role in cardiovascular diseases. ${ }^{14}$ Because of their smaller these show easy tissue penetration/retention and carry high amount of drugs in bound form to various tissues through circulation system..$^{15}$ These also function as a lipid scavenger and removes harmful bad cholesterol. Hence, an elevated level of HDL lower downs risk of developing coronary heart diseases. ${ }^{16} \mathrm{HDL}$ reuses and recycles LDL cholesterol by transporting it to the liver where cholesterol molecule is reprocessed. HDL scavenges extra cholesterol deposited on the inner walls of blood vessels. Besides natural HDL molecules, reconstituted high density lipoprotein (rHDL) is also prepared to deliver therapeutic agents. Reconstructed high density lipoproteins (HDL) are used to deliver a lipophilic anticancer drug. rHDL is biocompatible, safe, nano-vector that mimics the physical, chemical as well as physiological properties 
of native high density lipoprotein (HDL). ${ }^{17}$ These are reconstituted with phospholipids and apolipoproteins and used as a vehicle for systemic delivery of drugs, therapies and as imaging agents. ${ }^{17}$ These are highly useful for targeted and efficacious systemic delivery of siRNAs. ${ }^{18}$ Besides, rHDL, discoidal high-density lipoproteins are also generated by the apolipoprotein-mediated solubilization of membrane lipids in vivo. ${ }^{19}$ These discoidal SMAaf-based lipid nanoparticles carry drugs deep into tissues mainly to metastatic sites (Table 1 ). ${ }^{20}$

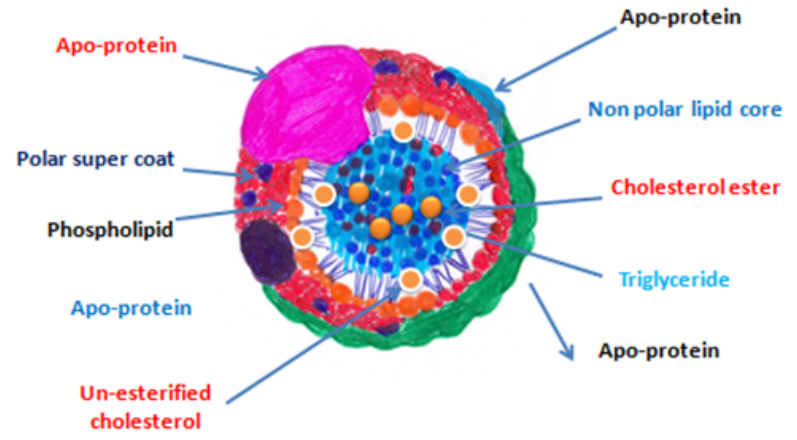

Figure I Lipoprotein serves as a carrier for transporting lipids.

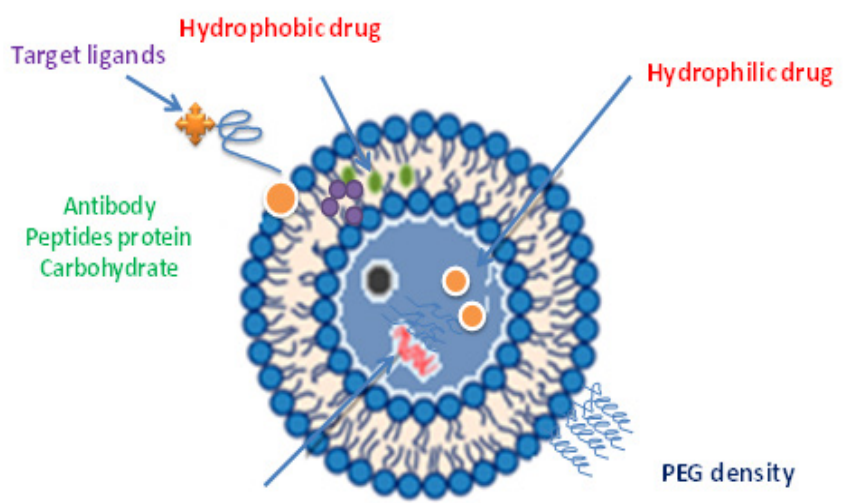

DNA/RNA/siRNA

Figure 2 Lipoprotein as a targeted drug carrier.

Low-density lipoprotein (LDL) carries cholesteryl esters to peripheral cells. It contains one major apolipoprotein (i.e. apo B-100), that allows LDL to bind to the LDL receptors on the peripheral cell surfaces. From where it is internalized by cells through a receptor mediated endocytosis. LDL is the endogenous carrier of cholesterol. The majority of cholesterol is obtained through the LDL receptormediated endocytosis mostly in the form of cholesterol ester. LDL particle is just like an oil droplet that is covered by a monolayer of phospholipid (Figure 3). LDL contains a lipid core that is made up of triglycerides (20\%) and cholesteryl esters (80\%). Low-density lipoprotein acts as a vehicle for targeting antitumor compounds to cancer Cells. ${ }^{21} \mathrm{LDL}$ is highly useful carrier molecule for hydrophobic drugs, but only lipophilic drugs partition into the core of the system. Since cholesterol is transported in ester from that is a native component of LDL. However, conjugation of an antitumor moiety with cholesterol facilitates the loading of drugs into LDL. Biocompatible, lipid-protein complexes are also ideal for loading and delivering cancer therapeutic and diagnostic agents. Natural lipoproteins and synthetic/reconstituted lipoproteins are widely used in clinical applications, particularly for cancer diagnostics/imaging and chemotherapy.

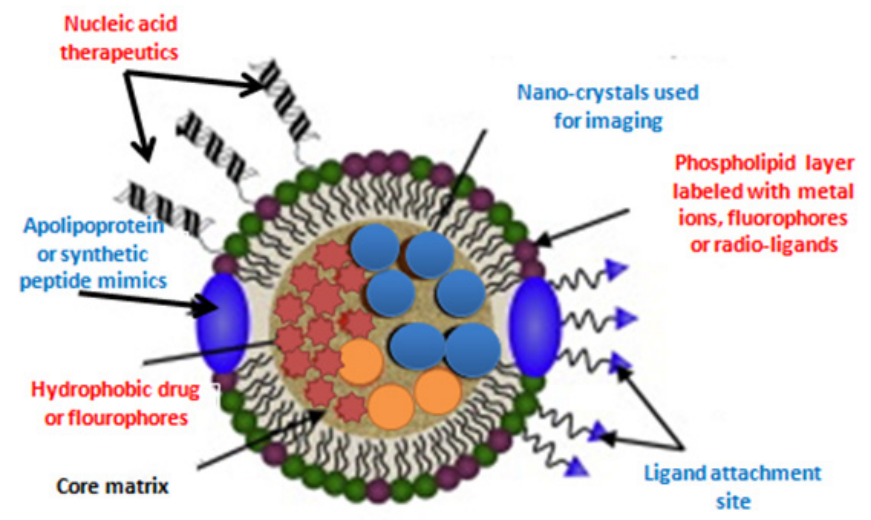

Figure 3 Lipoproteins and lipoprotein mimetics for imaging and drug delivery.

Table I Important properties of various lipoproteins

\begin{tabular}{|c|c|c|c|c|}
\hline Parameter & CM & VLDL & LDL & HDL \\
\hline Diameter (nm) & $75-1200$ & $30-80$ & $19-25$ & $5-12$ \\
\hline Density (g/ml) & $<0.96$ & $\begin{array}{l}0.96- \\
1.006\end{array}$ & $\begin{array}{l}1.019- \\
1.063\end{array}$ & $1.063-1.210$ \\
\hline Mw. & 400 & Oct-80 & 2.3 & $0.17-0.36$ \\
\hline source & Gut & Liver & $\begin{array}{l}\text { VLDL/ } \\
\text { ILDL }\end{array}$ & Gut, Liver \\
\hline Size & $75-1200 \mathrm{~nm}$ & $\begin{array}{l}30- \\
80 \mathrm{~nm}\end{array}$ & $25-35 \mathrm{~nm}$ & $8-12 \mathrm{~nm}$ \\
\hline \multirow[t]{2}{*}{ Half life } & $5-13 \min$ & $2-5 \mathrm{~min}$ & $15 \mathrm{hr}$ & $11-12 \mathrm{hr}$ \\
\hline & B48 & $\mathrm{B} 100$ & $\mathrm{~B} 100$ & \\
\hline \multicolumn{5}{|l|}{$\begin{array}{l}\text { Lipid } \\
\text { composition }\end{array}$} \\
\hline Triglyceride & $80-95$ & $45-65$ & $18-22$ & $2-7$ \\
\hline Free cholesterol & $\mathrm{I}-3$ & $4-8$ & $6-8$ & $3-5$ \\
\hline Cholesterol ester & $2-4$ & $6-22$ & $45-50$ & $5-20$ \\
\hline Phospholipid & $3-6$ & $5-20$ & $18-24$ & $26-32$ \\
\hline Apolipoproteins & A-I,A-II,A-IV & & & A-I,A-II,A-IV \\
\hline
\end{tabular}

Lipoprotein density and presence of cholesterol in it causes cardiovascular problems. Density also decides the presence of cholesterol in blood exhibit hypo- and/or hypercholesterolemia and triglyceridemia. Lipid transfer between lipoproteins is a part of reverse cholesterol transport. It takes place in the cell cytoplasm as well as sub-organelles. Lipoprotein free cholesterol ratio is a positive regulator of the pathways involved in sterol clearance. It modulates lipid transfer by altering the availability of CE and TG to LTP at the lipoprotein surface..$^{22}$ Chylomicrons are the largest lipoproteins produced in the intestinal tract. Their main function is transport of dietary triglycerides and cholesterol. Very Low Density Lipoproteins 
(VLDL) is synthesized in the liver that transport triglyceride to peripheral tissues. LDLR (LDL receptors) regulate the behavior of VLDL/LDL-associated drugs. These VLDL/LDL bound drugs are cleared from the body by lipoprotein apheresis, a blood purification therapy that selectively removes VLDL/LDL particles from the bloodstream. This clearance also influences transport, metabolism, and the efficacy of drugs in humans. In present review article lipoprotein-based delivery are explained with their composition, target specificity and therapeutic efficacy and their use for delivery of poor water soluble drugs. ${ }^{2}$

\section{Types of lipoprotein based drug delivery systems}

\section{Liposomes or unilamellar vesicles}

Liposomes are carrier vehicles of therapeutic drugs mainly in fluid state. These display natural binding to LDL receptors and carry anticancer agents to deliver them in to the tissues (Figure 4). Further, drug delivery systems are also linked to ligands which could target these receptors. Liposomal anticancer drug delivery systems more efficiently distribute associated anticancer agents. Because slow and steady presence of liposomes in the blood lead to increase the therapeutic indices of the associated drugs. It results in an increase in the drug concentration in solid tumors and regions of infection and reducing the drug concentration. Furthermore, stability of liposomes in biological systems is very important in the targeting of anticancer agents. Because number of different factors influence liposomal integrity after introduction into the circulation such as: lipid-metabolism, exchange or transfer of liposomal lipid to plasma constituents or cellular membranes, interaction with plasma proteins, imperfect fusion of liposomes with cells involving partial release of entrapped material and release of lysosmal lipolytic enzymes during liposome induced endocytosis. ${ }^{23}$ Liposomes are safe as loaded drug has no chance to have resistance if used in cancer therapy. ${ }^{24}$ These are widely used to carry anticancer agents, ${ }^{25}$ polymer conjugates, ${ }^{26}$ bacterial ${ }^{27}$ and virus vectors. ${ }^{28}$ Liposomes are used as intravenous carriers of drugs and enzymes. Besides, drug delivery liposomes do mobilization of peripheral deposits of cholesterol. Liposomes are used to precede whole-particle uptake by receptors involved in lipoprotein metabolism. Liposomal contents also show direct interaction and disrupt membrane structure. ${ }^{29}$ Certain modifications in liposomes are possible by using varying quantity of lipid and drug type. It affects interactions liposome-lipoprotein interactions and sabotages the cancer cells at structure and show metabolic consequences as they are pH-sensitive. ${ }^{30}$

Lipid-based delivery vehicles, such as liposomes and oil emulsions are generally used for administration of water-insoluble photosensitizers. These are used in photodynamic therapy for treating tumours. ${ }^{6}$ Liposomes or oil vesicles are also prepared by using eggyolk or rat-liver phosphatidylcholine. For this purpose both lipids and lipoproteins (HDL) in aqueous phage are tagged on Ultrogel AcA34. ${ }^{31}$ But for formation of anionic liposomes lactosylated lowdensity lipoproteins (LDL) are also used as adjuvants for delivery of antisense oligonucleotides to Kupffer cells in liver. Liposomes are also formed from polymerizable diacetylenic phospholipids. ${ }^{32}$ Matrix metalloproteinase is used for release of liposomal contents that is formed by incorporating sequence-specific collagen-mimetic peptides MMP-9. More specially, encapsulating carboxyfluorescein (as a selfquenching fluorescent dye), is also used to form liposomes that also assists in detection and treatment of various human diseases. ${ }^{33}$ For delivery of Zn-phthalocyanine (ZnPc) and Sn-etiopurpurin (SnET2) incorporated in unilamellar liposomes or solubilized in a CremophorEL emulsion are intravenously provided to experimental animals. ${ }^{34}$

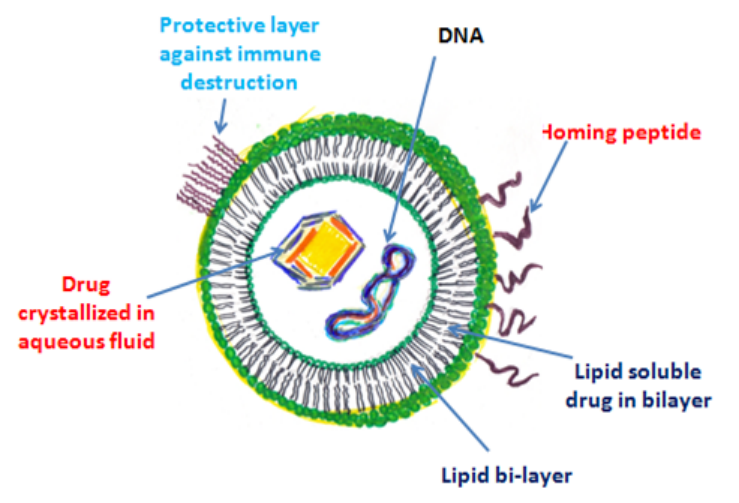

Figure $4 \mathrm{~A}$ typical liposome for drug delivery.

\section{LDL carrier vehicles}

Cholesterol is a major constituent molecule in low-density lipoproteins (LDLs). It plays important role in cellular homeostasis and production of steroids. Presence of higher levels of LDL in blood stream increases chances of a heart attack. High amount of LDL form bad plaque, and stuff that clog arteries and enhance the chances of heart attacks and strokes more likely. Low-density lipoproteins (LDLs) are internalized by the cell through receptor-mediated mechanisms (Figure 5). LDL is also taken up avidly by tumor cells to provide cholesterol for the synthesis of cell membranes. LDL is a good carrier of photosensitizer (berberine) in tumor cells. ${ }^{35}$ A synthetic nano-LDL (nLDL) particle containing paclitaxel oleate (nLDL-PO) was made by combining a synthetic peptide containing a lipid binding motif and the LDL receptor (LDLR) binding domain of apolipoprotein B-100 with a lipid emulsion consisting of phosphatidyl choline, triolein, and paclitaxel oleate. It is used as a drug delivery vehicle for glioblastoma multiforme. ${ }^{36}$ Similarly, a boronated analogue of LDL is synthesized that is used in boron neutron capture therapy. ${ }^{9}$ Both natural and reconstituted lipoproteins are used for various therapeutic purposes (Figure 6).

Low density lipoproteins (LDL) also act as a carrier for drug in emulsion. ${ }^{36}$ Acetylated low-density lipoprotein vehicle is developed that is chemically modified by the acetylation of lysine residues (AcLDL). This Ac-LDL carries anti-infectious drugs and its uptake is mediated through a specific scavenger receptor. Acetylated LDL-KOL is selectively accumulated through receptor-mediated assimilation within infected macrophages rather than in normal cells. ${ }^{38}$ More specifically, drug targeting occurs through by endogenous transport vehicles. ${ }^{39}$ Drug-low density lipoprotein complexes are used in treatment of intracellular infections. ${ }^{40}$ Reconstituted LDL is prepared by using lipophilic cytotoxic compound by two different methods. First method involves drug delivered to the cells via the LDL pathway that kill $100 \%$ of the cells. Another one is drug-delivery process via lipoprotein-type carriers, is the receptor-mediated uptake of the payload from the lipoprotein complex. ${ }^{2} \mathrm{~N}$-trifluoroacetyladriamycin14-valerate-LDL complex or LDL particle upload 100 drug molecules and send to vital organs. ${ }^{41}$ Apolipoprotein $\mathrm{B}$ is cell-penetrating 
peptides that efficiently deliver antigenic peptide. It binds to cell surface LDL receptor (LDLR) or cell surface-bound proteoglycans and is easily internalized into cells. ${ }^{42}$ Plasma lipoproteins are also used as drug carriers (Table 2). ${ }^{21}$

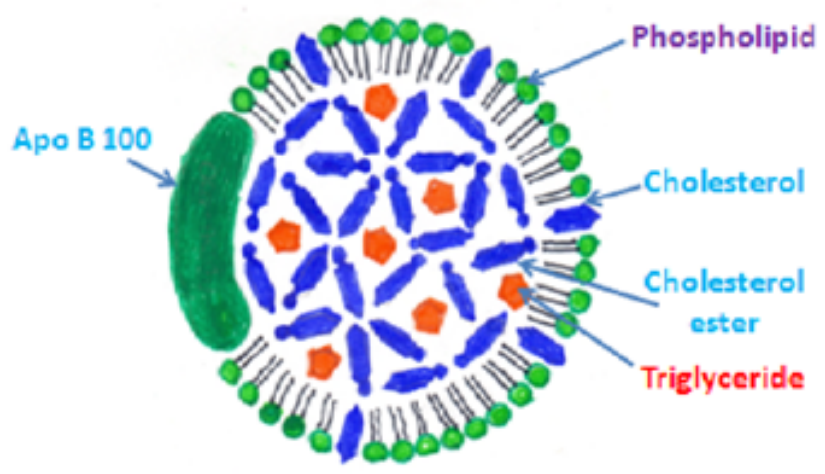

Figure 5 Structural components of a lipoprotein molecule.

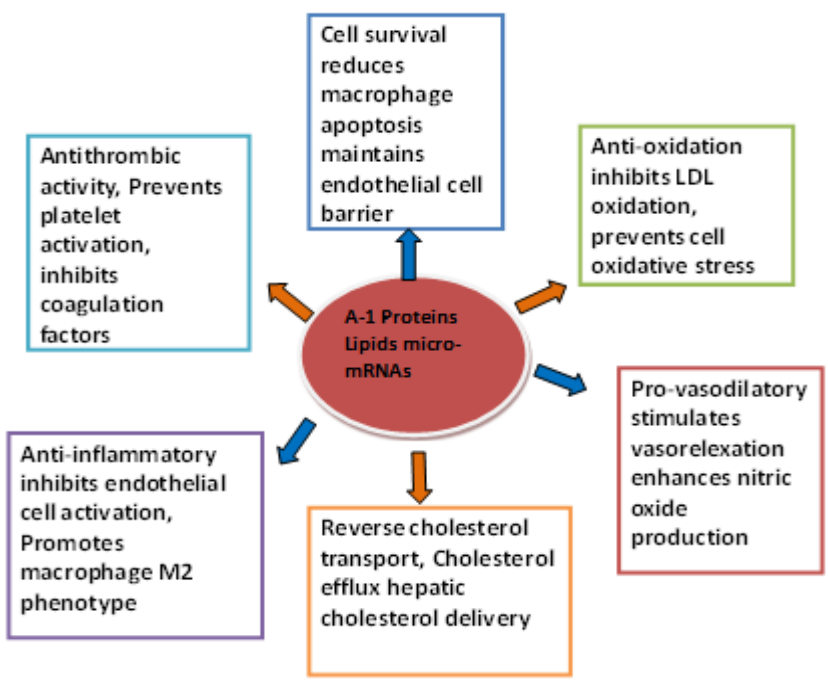

Figure 6 Use of lipoproteins for various therapeutic purposes.

\section{HDL carrier vehicles}

\section{Biomimetic HDL nanoparticles}

Biomimetic HDL-like nanoparticles (NP) can carry diverse groups of therapeutic agents such as chemotherapies, nucleic acids, proteins and carbohydrate colpexes. ${ }^{14}$ These smaller sized nanoparticles can freely navigate through interstitial space mainly for targeting tumors. ${ }^{43}$ These nanostructures possess high penetration/retention power and are used to deliver drugs in to intracellular space. These stream in circulation and for stay longer duration, can deliver clinically viable nanomedicines for cancer therapy. These particles are amphipathic apolipoproteins, lipid-loading and hydrophobic agent-incorporating characteristics. These manage protein-protein interactions and show heterogeneity ${ }^{15}$ and are showed great clinical application. ${ }^{44}$ These show feasibility and superiority as drug delivery vehicles because of their use in photodynamic therapy. An example a biomimetic HDL nanoparticle is indocyanine green used in enhanced photodynamic therapy. ${ }^{45}$

\section{Discoidal recombinant lipid nanoparticles}

Discoidal high-density lipoproteins d-rHDLs) are generated by the apolipoprotein-mediated solubilization of membrane lipids in vivo (Figure 7). These are also reconstituted with phospholipids and apolipoproteins in vitro. ${ }^{19}$ These are used to deliver anticancer agents those who show poor water-solubility and selectivity. These are biocompatible, biodegradable, and enter into cell through receptormediated endocytosis. d-rHDLs fused with paclitaxel show higher cellular uptake and it is cytotoxic to human breast cancer cells. ${ }^{46}$ These are prepared by thin-film dispersion/detergent dialysis. ${ }^{46}$ Similarly, recombinant high density lipoproteins are reconstituted with apolipoprotein AI cysteine mutants. It is used as delivery vehicles for 10-hydroxycamptothecin and showed targeted receptor-mediated uptake (Table 3). ${ }^{47}$

\section{Circulating HDL}

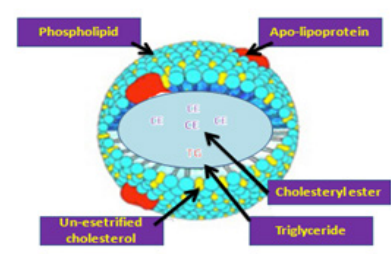

Reconstituted HDL

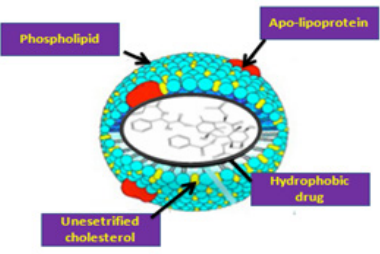

Figure 7 Diagrammatic diagrams of HDL and reconstituted HDL used for various therapeutic purposes.

\section{Recombinant high density lipoprotein}

Recombinant high density lipoprotein (rHDL) particles contain phosphatidylcholine, apolipoprotein A-1, cholesterol and cholesteryl esters in smaller concentration. These could bind three molecules of taxol per particle and form complexes. ${ }^{48}$ rHDL complexes can carry drug molecules deep into the tissues. ${ }^{49}$ These are also used as imaging agents ${ }^{50}$ and are better tolerated than the corresponding dosages of either Taxol or Abraxane. HDLs have diverse functions that provide significant opportunities for cancer therapy. ${ }^{51}$ Further, reconstituted high density lipoprotein (rHDL) is an excellent and highly biocompatible nanovector mimicking the physical, chemical as well as physiological properties of native high density lipoprotein (HDL). ${ }^{17}$ These vehicles are used to target tumor by delivering diverse drug payloads. ${ }^{13}$ Besides this, discoidal and spherical recombinant HDL particles loaded with cardiovascular drug tanshinone IIA (TA) are also reconstructed (TA-d-rHDL and TA-s-rHDL). Discoidal SMAafbased lipid nanoparticles are also constructed and used as delivery vehicles. rHDL could be especially used as potential delivery vehicles of targeting atherosclerotic lesions. ${ }^{43}$ 
Table 2 Plasma lipoproteins associate few drugs and carry them to target sites

\begin{tabular}{|c|c|c|c|c|c|}
\hline Compound & TRL & LDL & HDL & LDLP & Efficacy \\
\hline $\begin{array}{l}\text { Propranolol and } \\
\text { verapamil }\end{array}$ & & & & & $\begin{array}{l}\text { Lipophilic compounds, Lactosylation of LDL and HDL induces rapid, } \\
\text { galactose-specific uptake by Kupffer and parenchymal liver cells }\end{array}$ \\
\hline Amphpterici B & - & + & - & + & Amphotericin B lipid complex, show renal toxicity \\
\hline Abelcet & + & - & + & - & Decreased renal toxicity \\
\hline Cyclosporine A & + & + & + & - & Significant renal toxicity \\
\hline Halofantrine & + & + & + & - & Increased activity \\
\hline Clozapine & - & - & + & + & Increased activity \\
\hline Haldol & - & - & + & + & Increased activity \\
\hline Eritoran & + & - & + & - & investigational drug for the treatment of severe sepsis \\
\hline Amiodarone & + & + & + & + & $\begin{array}{l}\text { Antianginal and antiarrhythmic medication, synthetic lipid A antagonist that } \\
\text { blocks lipopolysaccharide (LPS) from binding at the cell surface MD2-TLR4 } \\
\text { receptor }\end{array}$ \\
\hline Paxleitexal & - & - & + & + & anti-cancer, plant alkaloid \\
\hline
\end{tabular}

Table 3 Showing various lipoprotein-based drug delivery systems used for transport of anticancer drugs to the site of action

\begin{tabular}{|c|c|c|c|}
\hline $\begin{array}{l}\text { Drug delivery } \\
\text { systems }\end{array}$ & Drug carrier & Target & Safety \\
\hline Polymers & $\begin{array}{l}\text { Inert carrier to which a therapeutic } \\
\text { is covalently linked, deliver drugs, } \\
\text { macromolecules, cells and enzymes }\end{array}$ & Therapeutic proteins to their target site & $\begin{array}{l}\text { Compatible, minimal or no toxic } \\
\text { profile. polysaccharide-based } \\
\text { polymers, }\end{array}$ \\
\hline Microcapsules & Lipophilic drug, pharmaceutics, & $\begin{array}{l}\text { Prolonged drug delivery of therapeutic } \\
\text { biomolecules }\end{array}$ & $\begin{array}{l}\text { Nano- and microcarriers depends } \\
\text { on their colloidal stability }\end{array}$ \\
\hline Micro-particles & $\begin{array}{l}\text { Materials, including ceramics, glass, } \\
\text { polymers, and metals }\end{array}$ & $\begin{array}{l}\text { Membrane-anchored receptors and } \\
\text { adhesion molecules, and transfer of } \\
\text { microRNA }\end{array}$ & $\begin{array}{l}\text { Safe, readily circulate in the } \\
\text { vasculature, serve as shuttle } \\
\text { modules and signaling transducers }\end{array}$ \\
\hline Liposomes & $\begin{array}{l}\text { Thin lipid films or lipid cakes are hydrated } \\
\text { and stacks of liquid crystalline }\end{array}$ & $\begin{array}{l}\text { Carriers for numerous molecules in } \\
\text { cosmetic and pharmaceutical industries }\end{array}$ & $\begin{array}{l}\text { Biocompatibility, } \\
\text { biodegradability, low toxicity, and } \\
\text { aptitude to trap both hydrophilic } \\
\text { and lipophilic drugs }\end{array}$ \\
\hline $\begin{array}{l}\text { Polysorbate coated } \\
\text { nanoparticles }\end{array}$ & Submicron drug carrier, temozolomide & $\begin{array}{l}\text { Mimic LDL to cross the BBB, and } \\
\text { enhance its brain-protective effects. }\end{array}$ & Safe \\
\hline $\begin{array}{l}\text { Polysaccharides and } \\
\text { co-polymers }\end{array}$ & Submicron drug carrier & $\begin{array}{l}\text { Drug delivery devices, controlled } \\
\text { release of fungicides, used for selective } \\
\text { water absorption from oil-water } \\
\text { emulsions, purification of water }\end{array}$ & $\begin{array}{l}\text { Non-toxic, biodegradable and } \\
\text { available at low cost }\end{array}$ \\
\hline Polyacetates & Submicron drug carrier & Deoxystreptaminel. & Potent tumor promoter \\
\hline $\begin{array}{l}\text { Colloidal drug } \\
\text { carriers }\end{array}$ & Emulsions, liposomes, nanoparticles & $\begin{array}{l}\text { Polyoxypropylene, polyethylene glycol, } \\
\text { ployoxyethylene }\end{array}$ & $\begin{array}{l}\text { Liposomes and NPs, increasing } \\
\text { drug efficacy and/or reducing their } \\
\text { toxicity }\end{array}$ \\
\hline
\end{tabular}




\section{HDL-like nanoparticles}

High-density lipoproteins (HDL)-like nanoparticles are used as drug carriers. ${ }^{52}$ Naturally HDL transports cholesterol throughout body. Due to their small size (5-100 $\mathrm{nm}$ in diameter) of lipoproteins these could carry therapeutic agents deep into tumors. HDL nanocomplexes are $\mathrm{pH}-$ responsive, undergo physicochemical changes and release enclosed drugs at acidic $\mathrm{pH}$ conditions.$^{53}$ For making them biocompatible these are coated with polyethylene glycol (PEG). Without PEG coating, particles are quickly trapped in the reticuloendothelial system when these are intravenously administered. ${ }^{52}$ HDL particles bind to their endogenous receptors, which also found on cancer cells. These lipoprotein nanocarriers mimic enzymes and can stay in circulation for much larger period, while largely evading the reticuloendothelial cells in the body's defenses. Thus lipoprotein and lipoprotein-based nanoparticles also serve much better than those other drug delivery vehicles. Phospholipid nanodiscs are also engineered for development of drug delivery systems. ${ }^{52}$ The incorporation of DLF into the rHDL nanoparticles protects against hydrolysis in the systemic circulation. DLF is used as a probe to track the movement and metabolism of HDL core constituents, including cancer chemotherapeutic agents. ${ }^{54}$

\section{Systemic delivery of siRNA therapeutics}

Short interfering RNAs (siRNAs) molecules are also used for therapeutics of many human diseases that follows gene silencing mechanisms. ${ }^{45}$ These are loaded on HDLs nanoparticles for systemic delivery. Synthesized biomimetic HDL is also being used as delivery vehicle for targeted and efficacious systemic delivery of siRNAs into the cytoplasm of the target cells. For intracellular delivery of siRNA, polymers with endosomolytic properties are used because they show endosomal escape. Apolipoprotein B is also used for efficient transfer of mRNA KD polyconjugates. ${ }^{55}$

\section{Ligand-coupled lipoprotein as drug delivery vehicles}

Lipoproteins are natural nano-sized delivery vehicles which stream within the circulatory system of all mammals. Normally lipoproteins loaded with medicinal agents are transported widely in body organs and tissues. Lipoprotein bound to some ligand could redirect natural lipoprotein receptors to an alternate receptor of choice. ${ }^{56}$ It assists in transport of endogenous macromolecules and therapeutic agents to specific cells or tissues in the body. More specifically, lipopeptide particles coupled in vivo are proved more useful as drug delivery vehicles. ${ }^{57}$ Liposome-based formulations are also prepared by using acetylated-LDL (Ac-LDL) as delivery vehicles for BPD (Table 4). ${ }^{58}$

\section{Lipid-based formulations for lymphatic delivery}

Chylomicrons based vehicles are prepared by administration of linoleic acid and arachis oil. These form high concentration of chylomicrons in the lymph but not generate VLDL or LDL. It depends on degree of unsaturation of the fatty acid, greater the unsaturation there will be more rapid onset of chylomicron. ${ }^{59}$ Probucol bound to chylomicron enhance lymphatic delivery by increasing the amount of the drug solubilized in propylene glycol or Transcutol HP. ${ }^{60}$ Lipophilic drugs are carried by chylomicrons that are secreted by the small intestine and transported in lymph (Table 5). ${ }^{61}$

Table 4 Ligand based drug/gene delivery methods used for treatment of hepatocellular carcinoma

\begin{tabular}{|c|c|c|c|}
\hline Delivery vehicle & Therapeutic agents & Ligand & Matching receptors \\
\hline Polyethylamine & Doxorubicin/shAktl & Glycyrrhetinic acid & Glycyrrhetinic receptor \\
\hline Dextran & Curcumin & & \\
\hline Polyethylamine & Plasmid PCMVluc27 & Epidermal growth factor & Epidermal growth factor \\
\hline $\begin{array}{l}\text { N-succinyl chitosan } \\
\text { LDL }\end{array}$ & $\begin{array}{l}\text { Doxorubicin/siRNA Osthole } \\
\text { Docasahexanoic acid }\end{array}$ & LDL & Low density lipoprotein receptor \\
\hline $\begin{array}{l}\text { Bovine serum } \\
\text { albumin }\end{array}$ & Doxorubicin & Hematoporphyrin & Low density lipoprotein receptor \\
\hline Lipoplexes & Chol-siRNA & Reconstituted high density lipoprotein & Scavenger receptor type B-I \\
\hline $\begin{array}{l}\text { Bovine serum } \\
\text { albumin }\end{array}$ & 5-flourouracil & Heat labile enterotoxin subunit B & Ganglioside GMI \\
\hline $\begin{array}{l}\text { Ruthenium } \\
\text { nanoparticles }\end{array}$ & $[\mathrm{Ru}(\mathrm{bpy}) 2(4-\mathrm{B})](\mathrm{ClO} 4) 2 . \mathrm{H} 2)$ & Epigallocatechin gallate & $67 \mathrm{kDa}$ laminin receptor \\
\hline Liposome & Plasmid DNA & $5-\mathrm{HT}$ & 5-HT receptor \\
\hline Liposome & Hydroxycamptothecine & Ocreotide & G-protein coupled receptors \\
\hline Liposomes & Hyaluronic acid & Extracellular matrix compound & $\begin{array}{l}\text { Specifically binds CD44 a biomarker } \\
\text { of cancer cells. CD44 is a membrane } \\
\text { protein that regulates various cellular } \\
\text { responses }\end{array}$ \\
\hline
\end{tabular}


Table Continued

\begin{tabular}{|c|c|c|c|}
\hline Delivery vehicle & Therapeutic agents & Ligand & Matching receptors \\
\hline LDL nanoparticles & Folate & $\begin{array}{l}\text { Folates produce and maintain new cells. } \\
\text { It transport folate-conjugates; thus, the } \\
\text { folate-drug conjugation can improve } \\
\text { tumor-targeted drug delivery. }\end{array}$ & $\begin{array}{l}\text { Participate in nucleotide synthesis, } \\
\text { folate receptors are highy over } \\
\text { expressed in cancer cells. }\end{array}$ \\
\hline Liposomes & $\begin{array}{l}\text { Polyunsaturated fatty acids ( } \alpha \text {-linolenic } \\
\text { acid; linoleic acid, arachidonic acid; } \\
\text { eicosapentaenoic acid; and docosahexaenoic } \\
\text { acid }\end{array}$ & $\begin{array}{l}\text { They can be attached to the tumor } \\
\text { cell membrane more easily, which } \\
\text { results in disruption fluidity of the cell } \\
\text { membranes. }\end{array}$ & $\begin{array}{l}\text { Tumor progression is reduced } \\
\text { by modulating } \mathrm{p} 53, \mathrm{p} 16 \text {, and } \mathrm{p} 27 \\
\text { expression and cell cycle regulation, } \\
\text { as well as by inducing cell death by } \\
\text { apoptosis and necrosis. }\end{array}$ \\
\hline Liposomes & Cholesterol & $\begin{array}{l}\text { Cancer cells take up } 100 \text { fold more low } \\
\text { density lipoprotein than normal cells } \\
\text { due to up-regulated LDL receptors in } \\
\text { cancer cells for membrane synthesis } \\
\text { during cell divison associated with } \\
\text { malignant transformation process. }\end{array}$ & $\begin{array}{l}\text { LDL is a good drug delivery vehicle } \\
\text { for carrying anticancer agents. }\end{array}$ \\
\hline Liposomes & $\begin{array}{l}\text { Polysaccharides, polyacrylamide polyvinyl } \\
\text { alcohol; polyvinylpyrrolidone; PEG-containing } \\
\text { copolymers (polyoxamers; poloxamines; } \\
\text { polysorbates; and PEG copolymers) }\end{array}$ & $\begin{array}{l}\text { Prevent opsonin binding to } \\
\text { nanoparticles. Recognition of } \\
\text { phagocytosis of nanoparticcles by the } \\
\text { mononuclear phagocytic system, }\end{array}$ & Enhance the blood circulation time \\
\hline Liposomes & Cationic surfactants & $\begin{array}{l}\text { The positive charge of cationic } \\
\text { surfactant interacts through } \\
\text { electrostatics with the negatively } \\
\text { charged phospholipids }\end{array}$ & $\begin{array}{l}\text { These are successfully exposed on the } \\
\text { cancer cell surface }\end{array}$ \\
\hline
\end{tabular}

Table 5 Synthetic HDL nanoparticles for the delivery of chemotherapeutic agents, siRNAs nanoparticles, and imaging agents

\begin{tabular}{|c|c|c|c|c|}
\hline Name & Lipid Type & $\begin{array}{l}\text { Lipoprotein } \\
\text { Component }\end{array}$ & Loaded drug & Target \\
\hline HPPS & $\begin{array}{l}\text { DMPC Cholesteryl oleate } \\
\text { (CO) }\end{array}$ & R4F peptide & $\begin{array}{l}\text { Paclitaxel oleate } \\
\text { DiR-BOA (optical } \\
\text { imaging contrast agent) } \\
\text { Cholesterol conjugated } \\
\text { siRNA }\end{array}$ & $\begin{array}{l}\text { Human KB subcutaneous tumor xenograft } \\
\text { Orthotopic prostate tumor xenograft }\end{array}$ \\
\hline sHDL & POPC & $\begin{array}{l}\text { L37pA and D37pA ApoA-I } \\
\text { mimetic peptides }\end{array}$ & $\mathrm{CO}$ & $\begin{array}{l}\text { Human umbilical vein endothelial cells I/R } \\
\text { injury rat heart model }\end{array}$ \\
\hline $\begin{array}{l}\text { HDL-mimicking } \\
\text { NP }\end{array}$ & $\begin{array}{l}\text { DSPE-PEG-COOH PLGA } \\
\text { CO }\end{array}$ & 4F peptide & $\begin{array}{l}\text { Quantum dot } \\
\text { conjugated to PLGA-b- } \\
\text { PEG Cationic stearyl- } \\
\text { triphenyl phosphonium }\end{array}$ & $\begin{array}{l}\text { Human adipose-derived MSCs Mouse } \\
\text { monocyte/macrophage RAW 264.7cells }\end{array}$ \\
\hline rHDL & $\begin{array}{l}\text { Egg yolk PC, cholesterol, } \\
\mathrm{CO}\end{array}$ & ApoA-I & $\begin{array}{l}\text { siRNA/oligolysine } \\
\text { mixture Paclitaxel } \\
\text { All-trans-retinoic acid } \\
\text { Fenretinide Valrubicin }\end{array}$ & $\begin{array}{l}\text { Human orthotopic ovarian tumor xenografts, } \\
\text { cancer cell lines (breast, prostate, ovarian), } \\
\text { Neuroblastoma cell lines, Retinal pigment } \\
\text { epithelial cells }\end{array}$ \\
\hline HDL-NP & PDP PE DPPC & ApoA-I & $\begin{array}{l}\text { 5nm gold nanoparticles } \\
\text { Antisense } \\
\text { cholesterylated DNA }\end{array}$ & Lymphoma cell lines Human cells \\
\hline VI56K- rHDL & POPC Cholesterol & ApoA-I & Rapamycin & $\begin{array}{l}\text { Human monocyte cell line Human dermal } \\
\text { fibroblasts Zebra fish model }\end{array}$ \\
\hline
\end{tabular}


Table Continued

\begin{tabular}{|c|c|c|c|c|}
\hline Name & Lipid Type & $\begin{array}{l}\text { Lipoprotein } \\
\text { Component }\end{array}$ & Loaded drug & Target \\
\hline $\begin{array}{l}\text { rHDL/Chol- } \\
\text { siRNA }\end{array}$ & $\begin{array}{l}\text { Soybean PC Cholesterol } \\
\text { Cholesteryl ester }\end{array}$ & ApoA-I & $\begin{array}{l}\text { Cholesterol conjugated } \\
\text { siRNA }\end{array}$ & $\begin{array}{l}\text { Liver cancer cell line Human liver } \\
\text { subcutaneous tumor Xenograft }\end{array}$ \\
\hline TA-rHD & $\begin{array}{l}\text { Glycerol trioleate } \\
\text { Cholesterol, CO }\end{array}$ & ApoA-I & Tanshinone IIA & Mouse macrophage cell line \\
\hline GBCA-HDL & & ApoA-I Synthetic peptide & $\begin{array}{l}\text { GBCA (MR contrast } \\
\text { agent) }\end{array}$ & $\begin{array}{l}\text { Macrophages ApoE-deficient mouse model of } \\
\text { atherosclerosis }\end{array}$ \\
\hline HDL & POPC & $\begin{array}{l}\text { L37pA and D37pA ApoA-I } \\
\text { mimetic peptides }\end{array}$ & $\mathrm{CO}$ & $\begin{array}{l}\text { Human umbilical vein endothelial cells I/R } \\
\text { injury rat heart model }\end{array}$ \\
\hline GBCA-HDL & ApoA-I Synthetic peptide & $\begin{array}{l}\text { GBCA (MR } \\
\text { contrast agent) }\end{array}$ & & $\begin{array}{l}\text { Macrophages ApoE-deficient mouse model of } \\
\text { atherosclerosis }\end{array}$ \\
\hline rHDL nanodiscs & DMPC & ApoE3-NT & Curcumin & $\begin{array}{l}\text { Construct bearing LDLR ligand binding } \\
\text { domains }\end{array}$ \\
\hline rHDL nanodiscs & DMPC & ApoA-I & Curcumin & $\begin{array}{l}\text { Human hepatocellular carcinoma cell line } \\
\text { Mantle cell lymphoma cells }\end{array}$ \\
\hline rHDL nanodiscs & DMPC & ApoA-I ApoE & Curcumin & Glioblastoma multiforme cells \\
\hline $\begin{array}{l}\text { Cationic rHDL } \\
\text { nanodiscs }\end{array}$ & $\begin{array}{l}\text { DMPC } \\
\text { Glycerophospholipid } \\
\text { DMTAP (cationic }\end{array}$ & ApoA-I & siRNA & Hepatoma cells \\
\hline rHDL nanodiscs & $\begin{array}{l}\text { Pyropheophorbide- } \\
\text { conjugated lipid }\end{array}$ & ApoA-I ApoE3 & Pyro & $\begin{array}{l}\text { SR-BI over-expressing cell line } \\
\text { (photosensitization) }\end{array}$ \\
\hline [S]-rHDL & Lyso PC DMPC & ApoA-I & Simvastatin & $\begin{array}{l}\text { Atherosclerotic plaques in Apo-E knockout } \\
\text { mice }\end{array}$ \\
\hline $\begin{array}{l}\text { HDL-mimicking } \\
\text { NP }\end{array}$ & $\begin{array}{l}\text { DSPE-PEG-COOH PLGA } \\
\text { CO }\end{array}$ & 4F peptide & $\begin{array}{l}\text { Quantum dot } \\
\text { conjugated to PLGA-b- } \\
\text { PEG Cationic stearyl- } \\
\text { triphenyl phosphonium }\end{array}$ & $\begin{array}{l}\text { Human adipose-derived MSCs Mouse } \\
\text { monocyte/macrophage RAW } 264.7 \text { cells }\end{array}$ \\
\hline $\mathrm{rHDL}$ & $\begin{array}{l}\text { Egg yolk PC, cholesterol, } \\
\text { CO }\end{array}$ & ApoA-I & $\begin{array}{l}\text { siRNA/oligolysine } \\
\text { mixture Paclitaxel } \\
\text { All-trans-retinoic acid } \\
\text { Fenretinide Valrubicin }\end{array}$ & $\begin{array}{l}\text { Human orthotopic ovarian tumor xenografts } \\
\text { Human cancer cell lines (breast, prostate, } \\
\text { ovarian) Neuroblastoma cell lines, Retinal } \\
\text { pigment epithelial cells Prostate and ovarian } \\
\text { cancer cell lines }\end{array}$ \\
\hline HDL-NP & PDP PE DPPC & poA-I & $\begin{array}{l}5 \mathrm{~nm} \text { gold nanoparticles } \\
\text { Antisense } \\
\text { cholesterylated DNA }\end{array}$ & Lymphoma cell lines Human cells \\
\hline VI56K- rHDL & POPC Cholesterol & ApoA-I & Rapamycin & $\begin{array}{l}\text { Human monocyte cell line Human dermal } \\
\text { fibroblasts Zebra fish model }\end{array}$ \\
\hline
\end{tabular}

\section{Drug delivery using nanotherapeutic molecules}

\section{Nanovectors}

Lipoprotein nanostructures such as nanovectors are also used in nanotherapeutics. ${ }^{62}$ These show high compatibility and better performance and are also used in photodynamic therapy (PDT) ${ }^{62}$ In PDT a photosensitizer is delivered with lipoproteins mainly by using lipid-based and Pluronic P123 formulations. These formulations are especially used for treatment of arthritis. ${ }^{63}$ Drug-loaded human low density lipoproteins carry adriamycin derivative AD 32 or the $\mathrm{N}$-mustard derivative WB $4291 .^{64}$ Cremopfore EL is an important vehicle for the administration of hydrophobic drugs. ${ }^{38}$ It effects distribution of taxol (anticancer) to serum lipoproteins (LDL). ${ }^{65}$ Changes on lipoprotein composition can be attributed mainly to cremophor vehicle, by using ethanol contents. ${ }^{66}$ Oily nano vehicles are also used to deliver drugs in lymphatic system. ${ }^{67}$ Lipophilic drugs incorporated in lactosylated HDL are taken up rapidly and selectively by parenchymal liver cells. ${ }^{68} \mathrm{rHDL}$ is used for incorporation and transport of hydrophobic and amphipathic bio-molecules. Table 6

\section{Nanodisks}

Nanodisks (ND) are self assembled nanoparticles which are composed of phospholipid and apolipoprotein. Nanodisks are formulated with inclusion of significant amounts of bioactive agents. ${ }^{69}$ Besides this, nanodiscs or "bicelles" are also constructed by using chemically and genetically engineered high-density lipoprotein (HDL). Its initial "nascent" form i.e. $10 \mathrm{~nm}$ disc of phospholipids fits in a bilayer, and can be easily synthesized in vitro by mixing recombinant apoA-I proteins with various phospholipids. ${ }^{70}$ Nascent high density lipoprotein (HDL) particle is reconstituted (rHDL) naturally by self arrangements of phospholipids in a disk-shaped 
bilayer with two or more apolipoprotein molecules circumscribing the edge of the disk. Nanodisks are biocompatible and their assembly is facile. These could be designed with high targeting specificity to finish tumors growth. ${ }^{71}$ Protein chimeras are used in targeting drug-enriched ND to specific tissues. These are used to load therapeutic molecules mainly antimicrobial agents. Members of the class of exchangeable apolipoproteins possess the unique capacity to transform phospholipid vesicle substrates into nanoscale disk-shaped bilayers. Apolipoprotein chimera is also prepared by fusion of protein that recognize the antigen to which the alpha-vimentin scFv is (single chain variable antibody). Further, apolipoprotein scaffold, interchangeability transfer lipid and scaffold components, makes ND a versatile delivery platform. ${ }^{71}$ Apolipoprotein A-I is used in ND formation and antigen recognition.
Nanodisk vehicle is prepared for delivery of curcumin, a polyphenol having anti-cancer properties. Incorporation of curcumin into ND generates a water soluble formulation suitable for intravenous delivery. ${ }^{72}$ Similarly, two distinct water insoluble drugs AMB-ND (amphotericin B) display potent anti-fungal and anti-protozoal activity, ATRA-ND (all trans retinoic acid) are also transferred by using nanodisks for treatment of cancer. ${ }^{73}$ Cationic lipid is included in the ND formulation that generates intact nanometer sized positively charged ND. Cationic lipid ND stably bound 23-mer double stranded oligonucleotides. Cationic lipid ND-bound siRNA efficiently knocked down a target gene in hepatocarcinoma cells. Drug delivery via lipoprotein-based carriers is best model to transport therapeutic agents to the site of invasion and metastasis. ${ }^{74,75}$

Table 6 Examples of synthetic LDL nano-particles

\begin{tabular}{lllll}
\hline Name & Lipid component & $\begin{array}{l}\text { Lipoprotein } \\
\text { component }\end{array}$ & Cargo & Target \\
\hline Nano-LDL & PC-Triolein & ApoB mimetic peptdie & Paclitaxel oleate & Glioblastoma multiforme cells \\
sLDL & Egg yolk PC & ApoB mimetic peptide & Lymphoma cell line \\
rLDL & Extracted LDL Trolein & ApoB & Bacteriochlorin e6 & PDT in human liver subcutaneous tumor \\
rITG)LDL & Extracted LDL & ApoB & Poly-iodinated triglyceride & Liver cancer cells \\
LDL/dextran & Extracted LDL & ApoB & Hypericin & Human glioma cell line \\
Au-LDL & LDL & ApoB & Au-MHPC & CT and optical imaging in subcutaneous \\
\end{tabular}

\section{Conclusion}

Lipoprotein-based drug delivery systems are efficient vehicles which carry anticancer drugs to the site of invasion. LP based strategies also assist in improving the therapeutic efficacy of drugs thus unsuitable or drugs with poor solubility and of limited application would have shown good action. Further, a step is needed to develop innovative drug delivery approaches to increase the target specificity of anticancer and antitumor drugs and lower down of their toxicity. For this purpose LPs and their sub-constituents can be used for making for drug delivery with sequestering of cholesterol from intracellular space. Three aspects LDL bound to drugs, LDL as nano carriers and boron capture therapy could assist more and more. In all approaches natural, bio-compatible, materials should be used. Therapeutic agents are transferred through receptor mediated endocytosis in cancer cells. There is a need to develop reconstituted lipoprotein drug delivery systems or nanodisks carriers, biophysical attachment of metals/drugs to lipid carrier particles and shuttling agents for increasing clinical applications of LDL systems particularly for cancer diagnostics/ imaging and chemotherapy. Targeting moieties are antibodies, charged molecules, proteins, lipoproteins, polysaccharides, low weight molecular weight ligands, hormones.

\section{Acknowledgements}

Author is thankful to Prof. R.N.K. Bamezai, former dean School of Life Sciences, JNU New Delhi for important discussion and direction to write this paper in present from.

\section{Conflict of interest}

The author declares that there is no conflict of interest.

\section{References}

1. Thaxton CS, Rink JS, Naha PC, et al. Lipoproteins and lipoprotein mimetics for imaging and drug delivery. Adv Drug Deliv Rev. 2016;106(Pt A):116-131.

2. Sabnis N, Lacko AG. Drug delivery via lipoprotein-based carriers: answering the challenges in systemic therapeutics. Ther Deliv. 2012;3(5):599-608.

3. Gal D, Ohashi M, MacDonald PC, et al. Low-density lipoprotein as a potential vehicle for chemotherapeutic agents and radionucleotides in the management of gynecologic neoplasms. Am J Obstet Gynecol. 1981;139(8):877-885.

4. Cruz PM, Mo H, McConathy WJ, et al. The role of cholesterol metabolism and cholesterol transport in carcinogenesis: a review of scientific findings, relevant to future cancer therapeutics. Front Pharmacol. 2013;4:119.

5. Vitols SG, Masquelier M, Peterson CO. Selective uptake of a toxic lipophilic anthracycline derivative by the low-density lipoprotein receptor pathway in cultured fibroblasts. J Med Chem. 1985;28(4):451-454.

6. Reddi E. Role of delivery vehicles for photosensitizers in the photodynamic therapy of tumours. J Photochem Photobiol B. 1997;37(3):189-195.

7. Ivanov VO, Preobrazhensky SN, Tsibulsky VP, et al. Liposome uptake by cultured macrophages mediated by modified low-density lipoproteins. Biochim Biophys Acta. 1985;846(1):76-84. 
8. Torkhovskaia TI, Ipatova OM, Medvedeva NV, et al. Plasma lipoprotein as drug carriers. Effect of phospholipid formulations. Vestn Ross Akad Med Nauk. 2010;(5):42-50.

9. Laster BH, Kahl SB, Popenoe EA, Pate DW, Fairchild RG. Biological efficacy of boronated low-density lipoprotein for boron neutron capture therapy as measured in cell culture. Cancer Res. 1991;51(17):4588-4593.

10. Lambert D, Mourot J. Vitamin E and lipoproteins in hyperlipoproteinemia. Atherosclerosis. 1984;53(3):327-330.

11. Lamon-Fava S, Sadowski JA, Davidson KW, et al. Plasma lipoproteins as carriers of phylloquinone (vitamin K1) in humans. Am J Clin Nutr. 1998;67(6):1226-1231.

12. Gershkovich P, Hoffman A. Effect of a high-fat meal on absorption and disposition of lipophilic compounds: the importance of degree of association with triglyceride-rich lipoproteins. Eur J Pharm Sci. 2007;32(1):24-32.

13. $\mathrm{Xu} \mathrm{Y,} \mathrm{Jin} \mathrm{XF,} \mathrm{Ping} \mathrm{QN,} \mathrm{et} \mathrm{al.} \mathrm{Recent} \mathrm{development} \mathrm{of} \mathrm{natural} \mathrm{and}$ reconstituted lipoprotein based nano drug delivery vehicles. Yao Xue Xue Bao. 2014;49(1):23-29.

14. McMahon KM, Foit L, Angeloni NL, et al. Synthetic high-density lipoprotein-like nanoparticles as cancer therapy. Cancer Treat Res. 2015;166:129-150

15. Mutharasan RK, Foit L, Thaxton CS. High-Density Lipoproteins for Therapeutic Delivery Systems. J Mater Chem B. 2016;4(2):188-197.

16. Damiano MG, Mutharasan RK, Tripathy S, et al. Templated high density lipoprotein nanoparticles as potential therapies and for molecular delivery. Adv Drug Deliv Rev. 2013;65(5):649-662.

17. Wang X, Zhou J, Wang W. Reconstituted high density lipoproteinbased nanoparticles: an overview of applications in regenerative medicine, preparation, evaluation and future trends. Curr Pharm Des. 2015;21(12):1529-1544.

18. McMahon KM, Thaxton CS. High-density lipoproteins for the systemic delivery of short interfering RNA. Expert Opin Drug Deliv. 2014;11(2):231-247.

19. Tanaka M, Hosotani A, Tachibana Y, et al. Preparation and Characterization of Reconstituted Lipid-Synthetic Polymer Discoidal Particles. Langmuir. 2015;31(46):12719-12726.

20. Seki J, Okita A, Watanabe M, et al. Plasma lipoproteins as drug carriers: pharmacological activity and disposition of the complex of betasitosteryl-beta-D-glucopyranoside with plasma lipoproteins. J Pharm Sci. 1985;74(12):1259-64

21. Firestone RA. Low-density lipoprotein as a vehicle for targeting antitumor compounds to cancer cells. Bioconjug Chem. 1994;5(2):105-113.

22. Morton RE, Greene DJ. Partial suppression of CETP activity beneficially modifies the lipid transfer profile of plasma. Atherosclerosis. 2007 May;192(1):100-107.

23. Shaw JM. Delivery of lipophilic drugs using lipoproteins. Annals NY Acad Sci. 1990;252-271.

24. Kreiger M, McPhaul M, Goldstein J, et al. Replacement of neutral lipids of low-density lipoprotein with esters of long-chain unsaturated fatty acids. J Biol Chem. 1979;254:3845-3853.

25. Park JW. Liposome-based drug delivery in breast cancer treatment Breast Cancer Res. 2002;4(3): 95-99.

26. Luo Y, Prestwich GD. Prestwich GD Cancer-targeted polymeric drugs Curr Cancer Drug Targets. 2002;2(3):209-226.
27. Bermudes D, Zheng LM, King IC. Live bacteria as anticancer agents and tumorselective protein delivery vectors. Curr Opin Drug Discov Devel. 2002;5(2):194-199.

28. Green NK, Seymour LW. Adenoviral vectors: Systemic delivery and tumor targeting. Cancer Gene Ther. 2002;9(12):1036-1042.

29. Williams KJ, Phillips MC, Rodrigueza WV. Structural and metabolic consequences of liposome-lipoprotein interactions. Adv Drug Deliv Rev. 1998;32(1-2):31-43.

30. Ponnappa BC, Israel Y. Targeting Kupffer cells with antisense oligonucleotides. Front Biosci. 2002;7:223-233.

31. Scherphof G, Roerdink F, Waite M, et al. Disintegration of phosphatidylcholine liposomes in plasma as a result of interaction with high-density lipoproteins. Biochim Biophys Acta. 1978;542(2):296-307.

32. Freeman FJ, Hayward JA, Chapman D. Permeability studies on liposomes formed from polymerizable diacetylenic phospholipids and their potential applications as drug delivery systems. Biochim Biophys Acta. 1987;924(2):341-351.

33. Sarkar N, Banerjee J, Hanson AJ, et al. Matrix metalloproteinaseassisted triggered release of liposomal contents. Bioconjug Chem 2008;19(1):57-64.

34. Polo L, Reddi E, Garbo GM, et al. The distribution of the tumour photosensitizers $\mathrm{Zn}(\mathrm{II})$-phthalocyanine and $\mathrm{Sn}(\mathrm{IV})$-etiopurpurin among rabbit plasma proteins. Cancer Lett. 1992;66(3):217-223.

35. Luiza Andreazza N, Vevert-Bizet C, et al. Berberine as a photosensitizing agent for antitumoral photodynamic therapy: Insights into its association to low density lipoproteins. Int J Pharm. 2016;510(1):240-249.

36. Nikanjam M, Gibbs AR, Hunt CA, et al. Synthetic nano-LDL with paclitaxel oleate as a targeted drug delivery vehicle for glioblastoma multiforme. J Control Release. 2007;124(3):163-171.

37. Kongshaug M, Cheng LS, Moan J, et al. Interaction of cremophor EL with human plasma. Int J Biochem. 1991;23(4):473-478.

38. Nicolas JM, Pirson P, Leclef B, et al. Acetylated low-density lipoprotein as a vehicle for antiinfectious drugs: preparation and antileishmanial activity of Ac-LDL containing ketoconazole-oleate. Ann Trop Med Parasitol. 1990;84(4):325-336.

39. Van Berkel TJ, De Smidt PC, Van Dijk MC, et al. Drug targeting by endogenous transport vehicles. Biochem Soc Trans. 1990;18(5):748-750.

40. Lundberg B. Preparation of drug-low density lipoprotein complexes for delivery of anti-tumoral drugs via the low density lipoprotein pathway. Cancer Res. 1987;47(15):4105-1408.

41. Masquelier M, Vitols S, Peterson C. Low-density lipoprotein as a carrier of antitumoral drugs: in vivo fate of drug-human low-density lipoprotein complexes in mice. Cancer Res. 1986;46(8):3842-3847.

42. Sakamoto N, Rosenberg AS. Apolipoprotein B binding domains: evidence that they are cell-penetrating peptides that efficiently deliver antigenic peptide for cross-presentation of cytotoxic T cells. J Immunol. 2011;186(8):5004-5011.

43. Zhang W, He H, Liu J, et al. Pharmacokinetics and atherosclerotic lesions targeting effects of tanshinone IIA discoidal and spherical biomimetic high density lipoproteins. Biomaterials. 2013;34(1):306-319.

44. Mo ZC, Ren K, Liu X, et al. A high-density lipoprotein-mediated drug delivery system. Adv Drug Deliv Rev. 2016;106:132-147.

45. Wang Y, Wang C, Ding Y, et al. Biomimetic HDL nanoparticle mediated tumor targeted delivery of indocyanine green for enhanced photodynamic therapy. Colloids Surf B Biointerfaces. 2016;148:533-540. 
46. Jia J, Xiao Y, Liu J, et al. Preparation, characterizations, and in vitro metabolic processes of paclitaxel-loaded discoidal recombinant highdensity lipoproteins. J Pharm Sci. 2012;101(8):2900-2908.

47. Zhang X, Chen B. Recombinant high density lipoprotein reconstituted withapolipoprotein AI cysteine mutants as delivery vehicles for 10-hydroxycamptothecin. Cancer Lett. 2010;298(1):26-33.

48. Lacko AG, Nair M, Paranjape S, et al. High density lipoprotein complexes as delivery vehicles for anticancer drugs. Anticancer Res. 2002;22(4):2045-2049.

49. McConathy WJ, Nair MP, Paranjape S, et al. Evaluation of synthetic/ reconstituted high-density lipoproteins as delivery vehicles for paclitaxel. Anticancer Drugs. 2008;19(2):183-188.

50. Damiano MG, Mutharasan RK, Tripathy S, et al. Templated high density lipoprotein nanoparticles as potential therapies and for molecular delivery. Adv Drug Deliv Rev. 2013;65(5):649-662.

51. Foit L, Giles FJ, Gordon LI, et al. Synthetic high-density lipoproteinlike nanoparticles for cancer therapy. Expert Rev Anticancer Ther 2015;15(1):27-34

52. Murakami T. Phospholipid nanodisc engineering for drug delivery systems. Biotechnol J. 2012;7(6):762-767.

53. Shin JY, Yang Y, Heo P, et al. pH-responsive high-density lipoprotein-like nanoparticles to release paclitaxel at acidic $\mathrm{pH}$ in cancer chemotherapy. Int J Nanomedicine. 2012;7:2805-2816.

54. McConathy WJ, Paranjape S, Mooberry L, et al. Validation of the reconstituted high-density lipoprotein (rHDL) drug delivery platform using dilauryl fluorescein (DLF). Drug Deliv Transl Res. 2011;1(2):113-120.

55. Parmar RG, Busuek M, Walsh ES, et al. Endosomolytic bioreducible poly(amido amine disulfide) polymer conjugates for the in vivo systemic delivery of siRNA therapeutics. Bioconjug Chem. 2013;24(4):640-647.

56. Corbin IR. Ligand-coupled lipoprotein for ovarian cancer-specific drug delivery. Methods Mol Biol. 2013;1049:467-480.

57. Lee KC, Lukyanov AN, Gelb MH, et al. Formation of high axial ratio microstructures from peptides modified with glutamic acid dialkyl amides. Biochim Biophys Acta. 1998;1371(2):168-184

58. Allison BA, Crespo MT, Jain AK, et al. Delivery of benzoporphyrin derivative, a photosensitizer, into atherosclerotic plaque of Watanabe heritable hyperlipidemic rabbits and balloon-injured New Zealand rabbits. Photochem Photobiol. 1997;65(5):877-883.

59. Cheema M, Palin KJ, Davis SS. Lipid vehicles for intestinal lymphatic drug absorption. J Pharm Pharmacol. 1987;39(1):55-56.

60. Kim H, Seong I, Ro J, et al. Enhanced association of probucol with chylomicron by pharmaceutical excipients: an in vitro study. Drug Dev Ind Pharm. 2015;41(7):1073-1079.
61. Shen H, Howles P, Tso P. From interaction of lipidic vehicles with intestinal epithelial cell membranes to the formation and secretion of chylomicrons. Adv Drug Deliv Rev. 2001;50 Suppl 1:103-125.

62. Norvaisas P, Ziemys A. The role of payload hydrophobicity in nanotherapeutic pharmacokinetics. J Pharm Sci. 2014;103(7):2147-2156.

63. Chowdhary RK, Sharif I, Chansarkar N, et al. Correlation of photosensitizer delivery to lipoproteins and efficacy in tumor and arthritis mouse models; comparison of lipid-based and Pluronic P123 formulations. J Pharm Pharm Sci. 2003;6(2):198-204.

64. Westesen K, Gerke A, Koch MH. Characterization of native and drugloaded human low density lipoproteins. J Pharm Sci. 1995;84(2):139-147.

65. Sykes E, Woodburn K, Decker D, et al. Effects of Cremophor EL on distribution of Taxol to serum lipoproteins. $\mathrm{Br} J$ Cancer. 1994;70(3):401-404.

66. Andrade RJ, Lucena MI, Gonzalez-Correa JA, et al. Short-term effect of various doses of cyclosporin A on plasma lipoproteins and its distribution in blood: an experimental study. Hum Exp Toxicol. 1993;12(2):141-146.

67. Ichihashi T, Kinoshita H, Takagishi Y, et al. Effect of oily vehicles on absorption of mepitiostane by the lymphatic system in rats. J Pharm Pharmacol. 1992;44(7):560-564

68. Bijsterbosch MK, Van Berkel TJ. Lactosylated high density lipoprotein: a potential carrier for the site-specific delivery of drugs to parenchymal liver cells. Mol Pharmacol. 1992;41(2):404-411.

69. Ng KK, Lovell JF, Zheng G. Lipoprotein-inspired nanoparticles for cancer theranostics. Acc Chem Res. 2011;144:1105-1113.

70. Ryan RO. Nanodisks: hydrophobic drug delivery vehicles. Expert Opin Drug Deliv. 2008;5(3):343-351.

71. Iovannisci DM, Beckstead JA, Ryan RO. Targeting nanodisks via a single chain variable antibody--apolipoprotein chimera. Biochem Biophys Res Commun. 2009;379(2):466-469.

72. Ghosh M. Nanodisk: a versatile drug delivery platform. USA: UC Berkeley; 2012.

73. Wasan KM, Morton RE, Rosenblum MG, et al. Decreased toxicity of liposomal amphotericin B due to association of amphotericin B with high-density lipoproteins: role of lipid transfer protein. J Pharm Sci. 1994;83(7):1006-1010.

74. Kongshaug M, Cheng LS, Moan J, et al. Binding of etiopurpurin and tin-coordinated etiopurpurin to human plasma proteins. Delivery in cremophore EL and dimethyl sulfoxide (paper II). Int J Biochem Cell Biol. 1995;27(1):71-87.

75. Kongshaug M, Moan J, Cheng LS, et al. Binding of drugs to human plasma proteins, exemplified by $\mathrm{Sn}(\mathrm{IV})$-etiopurpurin dichloride delivered in cremophor and DMSO. Int J Biochem. 1993;25(5):739-760. 